\title{
An English academic reading course for Dutch pre-university students
}

\author{
Loes Groen, Merel Keijzer, Marije Michel, and \\ Wander Lowie \\ University of Groningen
}

In this research note we argue that reading lessons for the subject of English in Dutch pre-university education require adjustments. Currently, these lessons do not prepare students well for university reading. Too often, lessons emphasize searching for information, the dominant skill to pass the school exit exam. Instead, students would benefit much more from instruction on reading to learn and critical reading, which are important university skills. Moreover, the expository texts for English classes generally concern school subjects instead of genuine English content such as linguistics. To address these problems, we are in the process of developing an academic reading course focussing on linguistic topics to enhance students' academic readiness, while at the same time adding depth and content to the subject of English in Dutch pre-university education. An empirical study to evaluate the effectiveness of this course will follow.

Keywords: academic reading course, strategies, pre-university education, linguistics, English lessons, Netherlands

\section{Introduction}

Research has shown that $20 \%$ of university students in the Netherlands struggle when reading academic texts in English (Wierda-Boer, 2008). This is a serious issue considering that $90 \%$ of academic sources at university are English-medium (SLO, 2018). This number of struggling students is quite high considering the prominent place of reading in the curriculum of pre-university level at Dutch secondary schools ('VWO'). Reading is the sole proficiency skill tested in the national exam, which means that reading constitutes $50 \%$ of the final mark for the school subject of English. As a result of the so-called backwash effect, much class time is spent on instruction on skimming and scanning, the reading strategies that 
suffice to answer most questions to the expository exam texts (Van de Wetering \& Groenendijk, 2015). Conversely, reading to learn tasks are typical of academic and professional settings where readers need to learn information (i.e. main ideas as well as details that elaborate the main ideas) from the text and link the text to their own knowledge bases (Grabe \& Stoller, 2011, p.292). Another reading skill that is indispensable to succeed at university, but which receives little attention at secondary school, is critical reading. Furthermore, in contrast to university programmes using texts containing discipline-specific content, many of the expository texts read in English class at secondary school appear random and relate to general subjects (e.g. money, sports, fashion). In doing so, the opportunity is eschewed to familiarize students with the rich and diverse content of linguistics. This is a lost opportunity, since it might inspire and motivate students to study the subject at university. In this paper we will explore the problems at stake, and offer possible solutions, which provided the basis for Read it!, a disciplinary academic reading course, which will be briefly introduced at the end.

\subsection{Reading to learn}

The English exam at Dutch secondary schools consists of approximately ten texts of different lengths accompanied by different questions tapping its content: multiple-choice, gapfill or comprehension questions, true-false questions, and short answer questions (Hoeflaak, 2012). To be able to answer these questions, it suffices to activate prior knowledge, skim topic sentences, and read questions that guide students through the text (Van de Wetering \& Groenendijk, 2015). Following the 'teaching-to-the-test' principle, reading texts in English lessons at secondary school are usually accompanied by questions that do not require whole-text processing. Not surprisingly therefore, Dutch students are good at searching for information in a text, but have more difficulties drawing inferences and critically evaluating the information (Cito, 2010).

To establish a continuous learning pathway between secondary school and university, students would benefit more from instruction in strategies that foster text comprehension. Text comprehension requires students to combine textual input and background knowledge to construct meaning. In contrast to skimming and scanning, reading to learn requires whole text processing, which is essential to studying the content of university course books (Van de Wetering \& Groenendijk, 2015). Besides text comprehension, the process of reading to learn encompasses evaluating knowledge and adjusting it accordingly based on the new information (Van den Broek, 2010). It involves more mental processes such as the reflection to foster memorisation (Grabe \& Stoller, 2011). Students would benefit from learning how to self-regulate the strategies that enable them to understand 
the text holistically, to adjust knowledge, and to learn the information accordingly (Van de Wetering \& Groenendijk, 2015; Westhoff, 2012). To optimize the relevance of English reading lessons in preparation for higher education, students should receive instruction in and practice metacognitive reading strategies allowing them to individually comprehend the gist of a text without being guided by questions. It is necessary for them to become aware of when, why and how to use different strategies, so they can apply them most effectively (Isakson \& Isakson, 2017).

Instruction in metacognitive reading strategies contributes to text comprehension and improved reading performance (Duke \& Pearson, 2002; Grabe \& Stoller, 2011; McNamara, 2007). This is also true for university reading (Isakson \& Isakson, 2017). Moreover, many studies distinguishing between poor and strong readers found that the latter apply more metacognitive reading strategies (Mokhtari \& Reichard, 2008). Applying metacognitive reading strategies fosters text interaction and thus enhances comprehension. It allows students to actively monitor comprehension, reread difficult passages or consult extra sources if needed to construct meaning, for example. The number of metacognitive reading strategies is extensive and numerous lists exist, most of which include a different selection of strategies (McNamara, 2007; Grabe \& Stoller, 2011). Many scholars seem to agree on organizing the strategies into in three stages to help guide students through the reading process: prereading strategies (e.g. setting purposes for reading, previewing, predicting and activating background knowledge), whilereading strategies (monitoring, clarifying and repairing, visualising, drawing inferences, thinking aloud, self-questioning), and post reading strategies (e.g. graphic organizer, summarising) (Duke \& Pearson, 2002; McNamara, 2007; Grabe \& Stoller, 2011). In addition, several authors underline the importance of the annotation strategy, which combines several reading strategies (McNamara, 2007; Fisher \& Frey, 2014; Porter-O’Donnell, 2004). Annotation forces students to actively interact with the text, fostering text processing and reading comprehension accordingly (Porter-O'Donnell, 2004). Duke mentions the gradual release of responsibility model, which moves from direct instruction (e.g. modelling), to guided instruction, to independent practice and collaborative learning to be an effective way to teach reading strategies (Duke \& Pearson, 2002).

\subsection{Critical reading}

Critical reading refers to being able to evaluate whether the authors' claims are valid by assessing arguments through asking critical questions: do the authors provide solid evidence for their stance and does the reasoning make sense? Does the article contain bias? This approach to reading receives little attention in the current Dutch curriculum, which prevents students from assessing the validity of 
the information and from forming opinions. As with the absence of reading to learn, the reason for the lack of attention is most likely to be found in the set-up of the current reading exam, which requires students to stick to the content of the text. Deviating from the content by making inferences, for example, often leads to an incorrect answer. Accordingly, students are discouraged to critically evaluate the content of the text. This dissuasion of critical reading is further reinforced by the limited time provided during exams, which requires students to skim and scan the text, but prevents them to fully take in the text and develop a critical attitude to what they have read (Westhoff, 2012). This has a backwash effect on the nature of the reading instruction throughout secondary school, which does not generally appeal to critical reading skills.

In contrast, critical reading is an indispensable part of university reading, since students have to be able to evaluate and synthesise scientific theories to establish their own opinions. To be able to question the validity of the author's arguments students need to learn how to draw inferences from the text while relying on their background knowledge and experience. To prepare students for this, this aspect of reading should be integrated in the secondary school curriculum (De Chazal, 2017).

Accepted scientific truths have all been contested and evaluated by other scientists before becoming widely accepted. Without arguments, theories cannot receive support. Throughout secondary school, however, students are given the impression that the information presented in schoolbooks for the diverse subjects is undisputed and, therefore, correct. Whereas teachers do provide explanations for the theory at hand, they hardly offer arguments to validate it. This results in students commonly believing the information in textbooks is authoritative and not subject to discussion once they enter university (Osborne, 2010). Conversely, learning about the nature of arguments and counterarguments, and in learning how to evaluate the different lines of reasoning presented in scientific texts and theories helps students to develop a critical attitude towards the information presented to them, which is needed to form opinions and to take a stance in the scientific debate.

\subsection{Content in the English lesson}

Except from some cultural related topics, the content of expository reading materials in the English lessons at Dutch secondary schools is often desultory and borrowed from other subjects. Topics addressed are sports, travel, or current affairs such as climate change and the IT-developments, for example. Which themes are addressed in the lesson and in what manner is decided by the publisher or the teacher. The root of this situation resides in the core curriculum standards that are 
mainly aimed at proficiency development and do not prescribe any content other than a small amount of literature to read (Meesterschapsteam MVT, 2018).

Instead of using interdisciplinary content, English reading texts could revolve more around cultural themes or other authentic content such as linguistics and culture. The field of linguistics is rich with its varieties such as psycholinguistics, sociolinguistics, historical linguistics and biolinguistics, and thus offers a window of opportunity to engage students with different interests. Throughout secondary school students could be familiarized with the richness of linguistics to obtain a good overview of the discipline. Following the successful CLIL-principle (studying a subject through a foreign language) students can learn authentic English content in English (Dale, Van der Es, \& Tanner, 2010)

The integration of linguistic topics into the curriculum would further enhance a learning pathway between the subject of English at secondary school and its Bachelor programme at university. The latter aligns with the view of the Nationaal Platform voor de Talen (Dutch Language Platform), which, amongst others, aims to provide secondary school students with a more comprehensive image of the university programmes to attract more students. Students need to discover that language programmes at university comprise a blend of knowledge and skills, and do not solely focus on improving proficiency (Nationaal Platform voor de Talen, 2019). These language programmes consist of more than literature and language skills; they have their own distinctive identity and texts about authentic topics just like other university programmes. The importance of linguistics contributing to a more complete image of the subject of English is supported by the so-called Meesterschapsteam of Modern Foreign Languages, which consists of university lecturers and educational experts (Meesterschapsteam MVT, 2018).

\section{English academic reading for pre-university students}

The logical implication of these observations is that there is considerable room for improvements in the reading programme of English at Dutch secondary schools to better prepare students for university. We are currently designing a disciplinary academic reading course (Read it!) to better prepare vwo students for university reading, while at the same time contributing to the relevance and identity of the subject of English. In ten lessons, students learn to critically process academic texts (e.g. evaluating the author's arguments and line for reasoning to form their own opinion) on linguistic topics while applying pre-, while- and post-reading strategies. Making annotations (which support the learning process) is at the heart of the course, which will go through two test cycles before it will be finalized. The 
reading strategies are introduced by means of inductive learning and the gradual release of responsibility model serves as the didactic method to help enable students to eventually apply the strategies independently. After six lessons, the course branches out in two trajectories to familiarize students with the field-specific textual aspects of their future studies: students who take social subjects read a text about globalisation, which combines aspects of history, social sciences and economics; and students who take natural subjects read a text about language and the brain, which combines elements of biology, chemistry and physics.

This way we aim to enhance students' academic readiness and improve the relevance of the subject of English accordingly, both reforms that are urgently needed. By identifying the main issues at hand, and by offering solutions, we have now outlined the theoretical foundation of our disciplinary academic reading course, which sets the ground for our future empirical study to test the effectiveness of Read it! at several Dutch vwo-schools.

\section{References}

Cito (2010). Resultaten PISA-2009 in vogelvlucht: Praktische kennis en vaardigheden van 15-jarigen. Retrieved from https://www.cito.nl/-/media/Files/kennis-en-innovatieonderzoek/pisa/cito_pisa_vogelvlucht_2009.pdf?la=nl-NL

Dale, L., Van der Es, W., \& Tanner, R. (2010). CLIL skills: Book on methodology for subject teachers in bilingual education. Leiden: Expertisecentrum Moderne Vreemde Talen.

De Chazal, E. (2017). English for academic purposes. Oxford: Oxford University Press.

Duke, N.K., \& Pearson, P.D. (2002). Effective practices for developing reading comprehension. In A.E. Farstrup, \& S. J. Samuels (Eds.), What research has to say about reading instruction (pp. 205-242). Newark, DE: International Reading Association.

Fisher, D., \& Frey, N. (2014). Close reading and writing from sources. Newark, DE: International Reading Association.

Grabe, W., \& Stoller, F.L. (2011). Teaching and researching reading (2de ed.). Harlow: Pearson Education.

Hoeflaak, A. (2012). Hoe transparant zijn de examens leesvaardigheid? Een reactie op "Samenvatten in het vreemdetalenonderwijs." Levende Talen Magazine, 99(3), 18-22.

Isakson, R.L., \& Isakson, M. B. (2017). Preparing college students to learn more from academic texts through metacognitive awareness of reading strategies. In K. Mokhtari (Ed.), Improving reading comprehension through metacognitive reading strategies instruction (pp. 155-176). Lanham, Maryland: Rowman \& Littlefield.

McNamara, D.S. (2007). Reading comprehension strategies: Theories, interventions and technologies. Mahway, NJ: Lawrence Erlbaum Associates. https://doi.org/10.4324/9780203810033

Meesterschapsteam Moderne Vreemde Talen. (2018). Visie op de toekomst van het curriculum moderne vreemde talen. Retrieved from https://modernevreemdetalen.vakdidactiekgw.nl /wp-content/uploads/sites/6/2018/o3/Aanbevelingstekst-MT-MVT.pdf 
Mokhtari, K., \& Reichard, C. (2008). The impact of reading purpose on the use of reading strategies. In K. Mokhtari, \& R. Sheorey (Eds.), Reading strategies of first and second language learners: See how they read (pp. 85-98). Norwood, MA: Christopher-Gordon Publishers.

Nationaal Platform voor de Talen (2019). Nationaal Platform voor de Talen. Retrieved from https://platformtalen.nl/activiteiten/

Osborne, J. (2010). Arguing to learn in science: The role of collaborative critical discourse. Science, 328(5977), 463-466. https://doi.org/10.1126/science.1183944

Porter-O’Donnell, C. (2004). Beyond the yellow highlighter: Teaching annotation skills to improve reading comprehension. English Journal, 93(5), 82-89. https://doi.org/10.2307/4128941

SLO (2018). Engels en moderne vreemde talen: Meewerken aan het onderwijs van morgen. Retrieved from https://slo.nl/@7630/startnotitie-engels/

Van den Broek, P. (2010). Using texts in science education: Cognitive processes and knowledge representation. Science, 328(5977), 453-456. https://doi.org/10.1126/science.1182594

Van de Wetering, T., \& Groenendijk, R. (2015). Van toetsgerichte lezers naar zelfstandige, analytische lezers: Geen trucje maar een vaardigheid. Levende Talen Magazine, 102(2), 4-8.

Westhoff, G. (2012). Mesten en meten in leesvaardigheidstraining: Leesvaardigheidstraining en examentraining zijn twee verschillende dingen. Levende Talen Magazine, 4(99), 17-20.

Wierda-Boer, H. (2008). Aansluiting Engels. Een onderzoek naar de aansluitings problematiek van het vwo-vak Engels met de universiteit. Nijmegen: IOWO.

\section{Address for correspondence}

\section{Loes Groen}

University of Groningen

Oude Kijk in 't Jatstraat 26

9712 EK Groningen

Netherlands

L.A.Groen@rug.nl

https://orcid.org/oooo-0oo2-7181-0639 


\section{Co-author information}

Merel Keijzer

University of Groningen

M.C.J.Keijzer@rug.nl

(iD) https://orcid.org/oooo-0oo1-9041-8563

Marije Michel

University of Groningen

M.C.Michel@rug.nl

(iD) https://orcid.org/oooo-0oo3-1426-4771

\section{Publication history}

Date received: 5 November 2019

Date accepted: 30 November 2020

Published online: 2 February 2021
Wander Lowie

University of Groningen

W.M.Lowie@rug.nl

(D) https://orcid.org/oooo-00o2-2241-0276 